\title{
The Investigation of Underpinning Factors in Effectiveness Sales Performance (Case Study：Food Industry in Iran)
}

\author{
Mohammad Taleghani ${ }^{1}$, Ataollah Taleghani ${ }^{2}$ \\ 'Associate Professor, Department of Industrial Management, Rasht Branch, Islamic Azad University, Rasht, Iran, \\ M.Taleghani454@yahoo.com \\ ${ }^{2}$ MSc Student of Engineering and Management, University of Politecnico di Torino, Torino, Italy \\ Taleghani.ata@gmail.com
}

\begin{abstract}
Key Words: sales

effectiveness

performance, strategic

decision-making,

marketing skills, sales

control management,

sales force performance,

environmental factors,

Iran.
\end{abstract}

\section{Introduction}

Companies are faced with significant challenges in their business environment, two of the primary ones being the constantly changing demand of customers and intensifying competition. Now, they need to find ways to improve their performance. In the contemporary world, the feasibility of mass production of commodities and services has allowed increasing supply versus demand; there is no way for producers to satisfy customers. Indeed, the domain of the market and supply cannot be defined by limited tools. Experience shows that organizations that take a traditional perspective on the concepts of customer, commodity, market, sales, purchase, competition, advertisement, quality, and so on are not only destined to fail but also lose their capitals and be eliminated from the market place (Abedi and Zavarei, 2017). In the meantime, the importance of sales and the use of different methods and tools to succeed in sales to companies cannot be exaggerated. Companies should adopt a proper way to sell their products. The enhancement of sales effectiveness is a key task of sales managers (Deeter and Schmelz, 2017). Today, companies are well aware of the significance of sales and attempt to maintain, stabilize, and/or improve their status in the markets' competitive climate by increasing their sales. Many factors are involved in achieving the goal of effective sales. For instance, the accomplishment of sales effectiveness requires skillful salespeople who can help companies realize their sales goals by recognizing customers' needs and problems and establishing effective relations with them (Tarafdar, 2014). In this respect, it is also important to consider intra-organizational communications quality, especially the relationships between management and sales human resource 
(Malek et al., 2018).Since sales strategies that companies develop for themselves can influence the effectiveness or inefficiency of sales (Dehdashti and Purhosseini, 2013), the present research aims to propose a model for better recognition of the factors influencing the effectiveness of sales of companies and the determination of their interrelations.

On the other hand, the issue of sales effectiveness is of higher importance in food industries because food producers are struggling with various challenges for the sale of their products, including economic turmoil, fierce competition, lack of liquidity, the bargaining power of retailers, and perishability. So, effective sales are a prime priority of all companies, which requires exploring the underlying factors and soundly planning for resolving the barriers of food production and sales. The first step to accomplish this goal is to identify the factors influencing the sales effectiveness of companies. A literature review reveals a range of factors within the categories of strategic-orientation of the company, sales management and control, marketing capabilities, and salesforce performance.

Accordingly, the research mainly aims to answer the question as to what the factors affecting the sales effectiveness of the companies are.

\section{Literature Review}

A literature review shows that organizational sales effectiveness can be influenced by environmental, organizational, and salesforce factors, some of which are enumerated here. The first factor that companies should be considered to ensure the effective sales of their products is to develop longterm key strategies. A strategic view of sales enables companies better to monitor the long-term barriers and drivers of sales, thereby enhancing their sales effectiveness (Panagopoulos and Avlonitis, 2010: 46). Researchers suggest that for successful admission into the market, a company needs to establish its strategic orientation towards customers and competitors and employ the innovations required for their production (Kue $\mathrm{Na}$ et al., 2019; Cacciolatt \& Lee, 2016; Tutar et al., 2015).
They should also have strategies to control production costs (Lee et al., 2015; Altuntas et al., 2013; Theodosiou et al., 2012). Researchers also argue that a strategy to gain competitive advantage and improve performance is the use of the differentiation strategy (Kaleka and Morgan, 2019; Cacciolatti and Lee, 2016; Lee et al., 2015; Murray et al., 2010). In other words, the company should have products that are unique as perceived by customers versus the similar products of the competitors. Brand orientation is also a concept that has been mentioned in the literature as a strategy for companies to accomplish optimal performance in their business (Gromark and Melin, 2011; Baumgarth, 2010). This means that the more the companies move towards establishing, developing, and protecting their brands, the better their business performance will be (REF and REF, 2011), and this is a key aspect of food product sales.

In addition to brand orientation, a company's success in selling its products requires a set of capabilities, which altogether came to be known as marketing capabilities (Dehdashti Sharokh et al., 2017). Ahmad et al. (2014) define marketing capabilities as the ability to exploit resources and inputs, e.g., financial resources and customer database, for optimal sales. Various research works have mentioned different capabilities as the marketing capabilities, including customer relationship management (Massiera et al., 2018), product management capability (Navarro-García et al., 2016; Morgan et al., 2009), pricing capability (Murray et al., 2011), distribution capability (Massiera et al., 2018; Martin et al., 2015), and product promotion capability (Navarro-García et al., 2016). In marketing, companies should have customer segmentation and customer prioritization, and targeting capabilities, too (Inyang et al., 2018). Other marketing capabilities that have less been noted in the research are sales domain design (Piercy et al., 2011) and retail network management (Massiera et al., 2018). Sales domain design refers to decisions on allocating customers to a specific salesforce, determining the geographical configura- 
tion of the sales units, and adjusting other parameters to provide an opportunity for the good performance of the individual salesforce (Cravens, 2015: 101). Poor designs adversely affect the performance of salesforce by limiting their opportunities, thereby affecting the organization's sales effectiveness (Piercy et al., 2011: 106).

One factor mentioned in the literature as one of the most effective sales effectiveness factors is the salesforce performance. A salesforce's performance includes different behavioral and outcome dimensions so that behavioral performance is the precursor of outcome performance (Fatima, 2015: 1). The behavioral performance of a salesforce refers to non-selling activities that the salespeople employ to improve their sales (e.g., customer-oriented selling skill, adaptive selling, teamwork, and technical knowledge). In contrast, outcome performance refers to the sales activity's quantitative results (e.g., sales volume and market share) (Agnihotri et al., 2017: 5). Research shows that the development of these two factors plays an essential role in organizations' sales effectiveness (Gustafson et al., 2018: 875).

A factor at the organizational level that may improve the behavioral and outcome performance of salespeople is a sales management and control system, which is by definition designed to condition the selling behavior of salespeople (Guenzi et al., 2013: 96) and even all activities of the company and its people. Sales controls are important for several reasons. They strongly influence a company's economic performance (Echchakoui, 2014) and its customer relationship because salespeople operate at the first line of a company (Albers et al., 2010). Besides, based on many companies' cost structure, it is vital to control the salesforce because they constitute the greatest part of the marketing people, and a great budget is spent on them. Consequently, designing mechanisms to control the salespeople's activities is a paramount field of sales research and activity (Malek et al., 2018: 3). Panagopoulos et al. (2015) note that the effective management of sales control should encompass formal and informal controls.

\section{Methodology}

The present research is a qualitative study based on grounded theory. This method uses an inductive approach to identify the underlying categories of the phenomenon in question. In the qualitative phase, the library and field methods were employed for data collection. The field part was composed of two instruments, i.e., in-depth (semi-structured) interviews and the coding of the collected data.

The statistical population was composed of all experts in sales effectiveness in food industries in Iran. The sample size was determined based on the principle of saturation. That is, the researcher kept collecting data as long as new categories or themes emerged, but when the data is saturated, the sampling stops. As such, the present research was saturated with 10 interviews.

\section{Results}

In the qualitative phase, the data collected from the interviews were analyzed by the coding method in the MAXQDA software package. They were then integrated with the theoretical framework and the conceptual model to develop the research hypotheses.

\subsection{Interview dataanalysis}

In this phase, the concepts, categories, and themes were discovered in the coding technique's interviews at three steps of open coding, axial coding, and selective coding. Table 1 presents the results of this analysis.

Refer Table On the next page 
Table 1 The results of the coding of the interviews

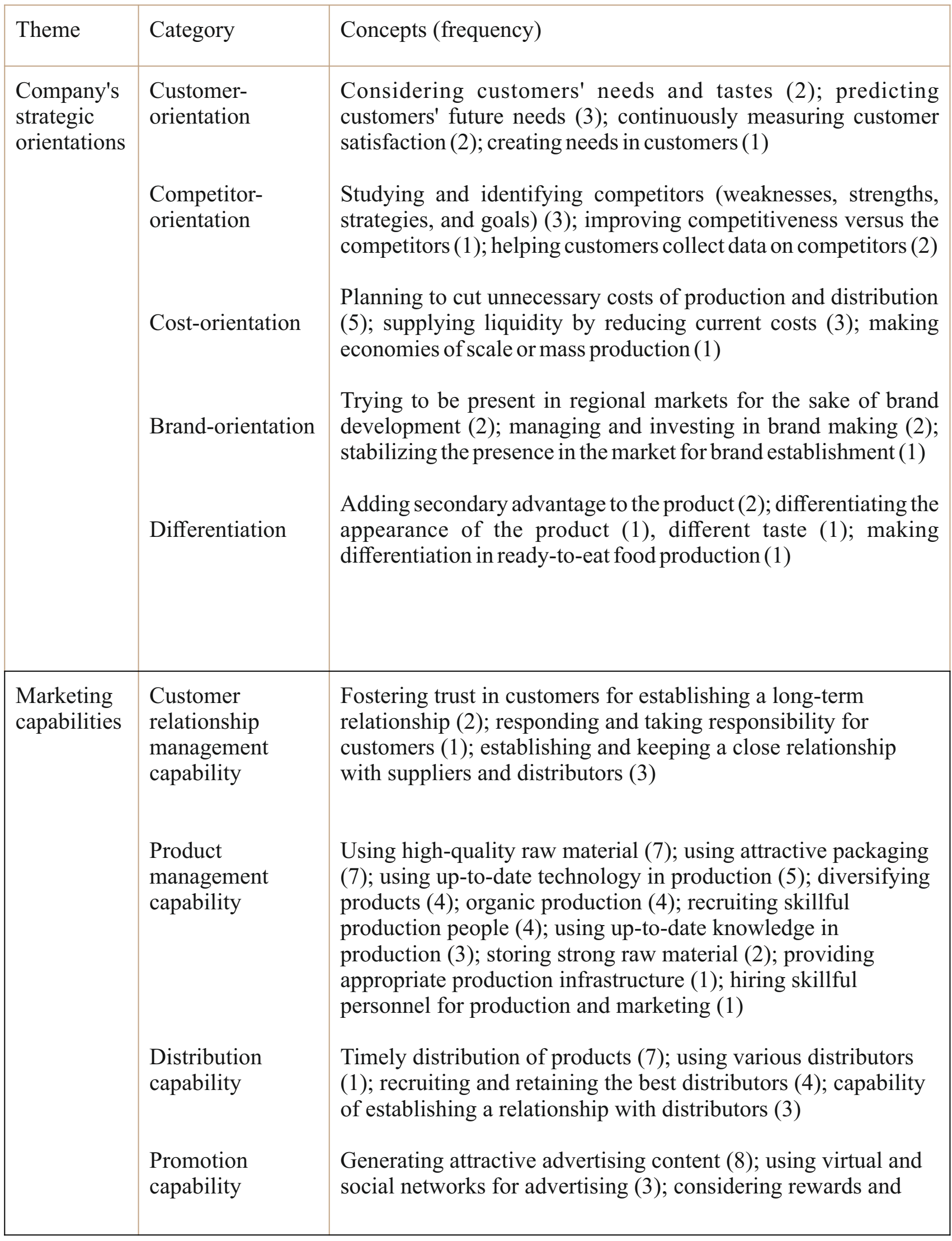


Sales domain designing capability

Retailing network management

discounts for customers (1); considering special occasions in the year for advertising (1); attending domestic and foreign exhibitions (1); directing government subsidies to promote healthy food (1)

Customer segmentation (based on their value or profitability, their demographic characteristics such as place of residence, or their buying behavior) (4); properly designing the geographical area of sales (2); prioritizing customers (based on their importance to the company) (2); determining the size of the salesforce for each domain (4); determining the deployment of a seller's sales time within customers in his or her area (2)

Establishing an appropriate mechanism for non-cash sales (6); suitable bids on goods for retailers (3); considering the appropriate profit margin for the retailer (1); selecting quality retailers (5)

Sales control management
Formal control

Information control
Continuously training the people (4); evaluating, improving and providing ongoing feedback on staff performance (3); Performance-based promotions and downgrading (1); holding challenging meetings with staff to remove obstacles (1); setting specific goals for personnel (3)

Motivating staff with material and spiritual gifts (4); encouraging staff to cooperate (2); creating an environment for mutual respect (2); creating an environment in which staff feel proud of the company (1)

\begin{tabular}{|l|l|}
\hline $\begin{array}{l}\text { Salesforce } \\
\text { performance }\end{array}$ & $\begin{array}{l}\text { Behavioral } \\
\text { performance }\end{array}$
\end{tabular}

Salesforce's experience (6); ability to establish a long-term relationship between salesforce and retailers (4); salesforce's commitment (3); salesforce's creativity (2); salesforce's character (2); salesforce's knowledge (knowledge of product features, company production processes and market) (2); flexibility in sales methods (3); using a wide range of sales approaches (3); efforts to provide the best product to the customer according to his or her needs (2); establishing strong working relationships with other people in the company (1); very close coordination with other employees of the company to address the problems of past sales and after-sales service (1) 


\begin{tabular}{|c|c|c|}
\hline \multirow{5}{*}{$\begin{array}{l}\text { Environment } \\
\text { al factors }\end{array}$} & $\begin{array}{l}\text { Outcome } \\
\text { performance }\end{array}$ & $\begin{array}{l}\text { The salesperson's ability to sell new products of the company } \\
\text { (3); the salesperson's ability to create more market share for } \\
\text { the company's products (2); the salesperson's ability to go } \\
\text { beyond the predetermined goals of the company in selling } \\
\text { products (2); the salesperson's ability to identify and sell } \\
\text { products to the main and effective buyers in the market (2) }\end{array}$ \\
\hline & Economic & $\begin{array}{l}\text { Economic fluctuations (10); instability in raw material prices } \\
\text { (1) } \\
\text { Weak government policymaking (6); lack of governmental } \\
\text { support (4); changes in governmental policies and laws (3); } \\
\text { lack of government monitoring of the market (2); improper } \\
\text { governmental quotas on raw materials (1); administrative } \\
\text { bureaucracy (1); unsupported licensing (1) }\end{array}$ \\
\hline & Socioeconomic & $\begin{array}{l}\text { Different market cultures (5); the reduced purchasing power } \\
\text { of the people (2) }\end{array}$ \\
\hline & Technology & $\begin{array}{l}\text { Technological changes in the market ( } 3) \text {; dependence on } \\
\text { foreign countries for raw materials and technology (1); weak } \\
\text { domestic technology (1) }\end{array}$ \\
\hline & Competitive & $\begin{array}{l}\text { Competition pressure in the market (7); extensive incentive } \\
\text { and promotion competitions in the industry (2) }\end{array}$ \\
\hline \multirow{4}{*}{$\begin{array}{l}\text { Organization } \\
\text { al sales } \\
\text { effectiveness }\end{array}$} & Investment & $\begin{array}{l}\text { Increased investment in business development (1); increased } \\
\text { investment in research and development (1) }\end{array}$ \\
\hline & Profitability & $\begin{array}{l}\text { Achieving profit margins versus the company's goals (3); } \\
\text { achieving profit margins versus competitors (1) }\end{array}$ \\
\hline & Market share & $\begin{array}{l}\text { Gaining market share versus the company's goals (4); gaining } \\
\text { market share versus competitors (2); gaining sales volume } \\
\text { versus the predetermined goals (2); gaining sales volume } \\
\text { more than competitors (2) }\end{array}$ \\
\hline & $\begin{array}{l}\text { Customer } \\
\text { satisfaction }\end{array}$ & $\begin{array}{l}\text { Satisfying customer expectations versus the predetermined } \\
\text { goals ( } 3 \text { ); satisfying customer expectations versus competitors } \\
\text { (2) }\end{array}$ \\
\hline
\end{tabular}

Based on the results, 287 concepts (considering the repetitions) were derived from the interviews at the open-coding step. After the concepts' connections were considered, they were reduced to 26 categories at the axial coding step. Finally, six themes were identified at the selecting coding step. After these steps were concluded, the research's paradigm and conceptual models were obtained based on the selective coding, which was drawn as shown in Figures 1 and 2 following consulting with the experts. 


\section{Available at: www.imperialpublications.com}

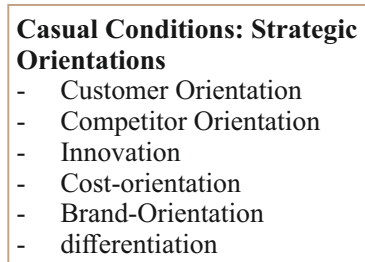

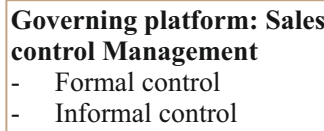

Main phenomenon:

Marketing capabilitie

- Product management

capability

- Pricing capability

- Distribution capability

- Retailing network

management

- Sales domain

designing
Approaches:Salesperson performance Behavioral performance

- Expericneced salesperson

- Committed salesperson

- Innovative salesperson

- A salesperson with character

- Knowledgeable salesperson

- Flexible salesperson

- A salesperson capable of creating long-term relationship

Outcome -performance

Mediating conditions:

External environmental

conditions

- Economics

Politics and

government

- Culture and

community

Technology

Competition intensity

Figure 1 The paradigm derived from the selective coding of the interviews

Figure 2 The conceptual model derived from the selective coding of the interviews in the MAXQDA software package

\subsection{The categories of the model}

A key aspect of grounded theory is the theoretical sensitivity or, in other words, the control of findings derived from the interviews through comparison with the previous theoretical framework. Accordingly, 66 papers in domestic journals and 120 papers in other countries' journals were assessed, whose results are presented in Table 2.

Table 2 The dimensions of the research model and the supporting literature (Source: Research findings)

\begin{tabular}{|c|c|c|c|c|}
\hline Theme & Definition & Category & $\begin{array}{l}\text { Supporting literature } \\
\text { (domestic) }\end{array}$ & $\begin{array}{l}\text { Supporting literature } \\
\text { (foreign) }\end{array}$ \\
\hline \multirow{3}{*}{$\begin{array}{l}\text { Company's } \\
\text { strategic } \\
\text { orientation }\end{array}$} & \multirow{3}{*}{$\begin{array}{l}\text { Strategic orientation } \\
\text { refers to how a company } \\
\text { adapts to the external } \\
\text { environment. It is also } \\
\text { used for specific } \\
\text { managerial perception, } \\
\text { readiness, willingnesses, } \\
\text { motivations, and }\end{array}$} & $\begin{array}{l}\text { Customer- } \\
\text { orientation }\end{array}$ & \multirow{3}{*}{$\begin{array}{l}\text { Habibi and Mira (1397); } \\
\text { Naiji et al. (1397); Dehdashti } \\
\text { Shahrokh et al. (2015); } \\
\text { Rahimnia and Sajjad (1394); } \\
\text { Hakimi (1396); Rahimnia et } \\
\text { al. (2012) }\end{array}$} & \multirow{3}{*}{$\begin{array}{l}\text { Adams et al. (2019); } \\
\text { Kuna et al. (2019); } \\
\text { Casiolati et al (2016), } \\
\text { Tatra et al. (2015), } \\
\text { Kumar Panda (2014), } \\
\text { Altantas et al. (2013), } \\
\text { Theodosius et al., 2012) }\end{array}$} \\
\hline & & $\begin{array}{l}\text { Competitor- } \\
\text { orientation }\end{array}$ & & \\
\hline & & $\begin{array}{l}\text { Innovation- } \\
\text { orientation }\end{array}$ & & \\
\hline
\end{tabular}


Available at: www.imperialpublications.com

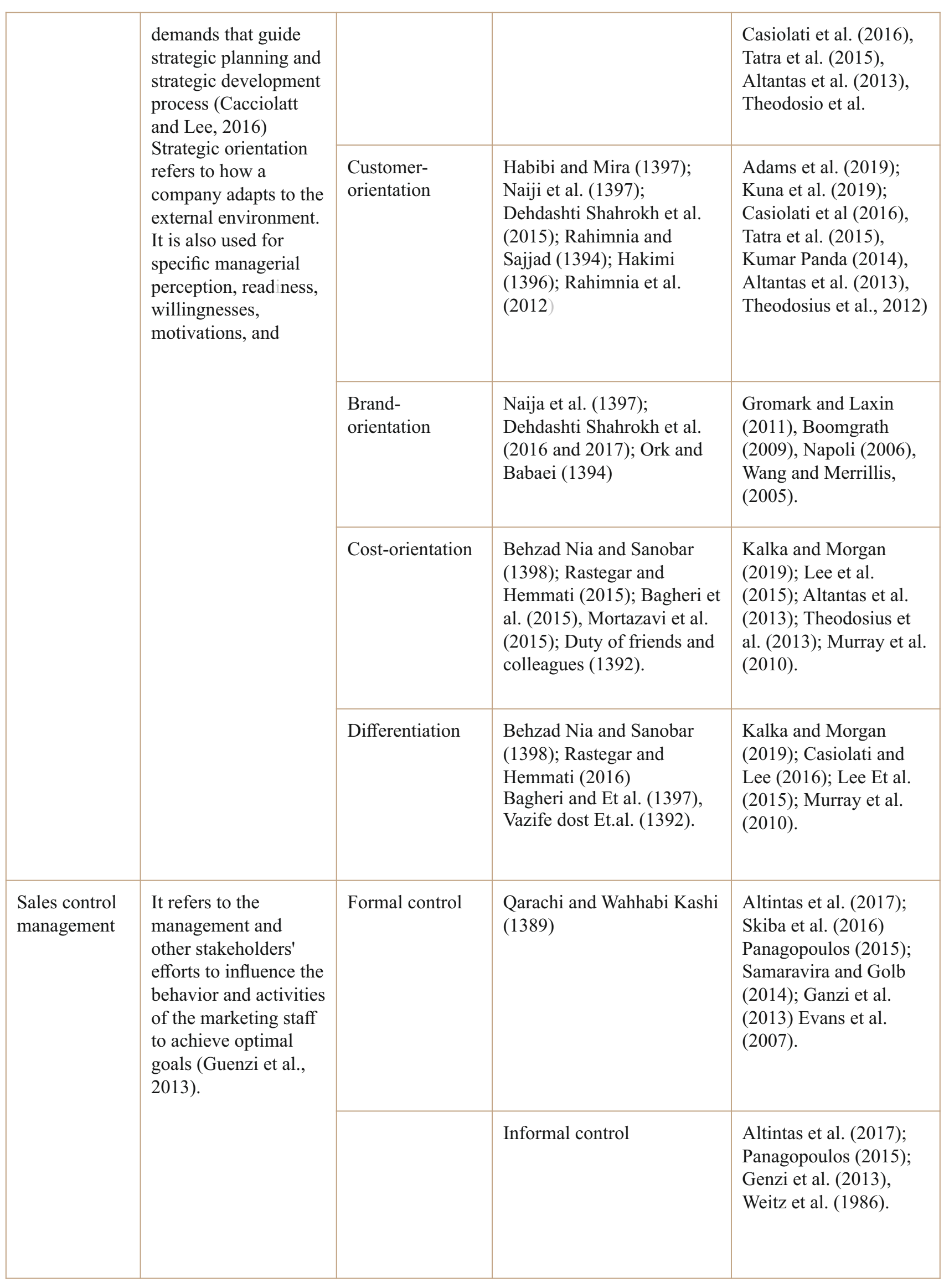


Available at: www.imperialpublications.com

\begin{tabular}{|c|c|c|c|c|}
\hline \multirow[t]{6}{*}{$\begin{array}{l}\text { Marketing } \\
\text { capabilities }\end{array}$} & \multirow[t]{6}{*}{$\begin{array}{l}\text { It refers to a } \\
\text { complicated set of } \\
\text { knowledge, skills, and } \\
\text { capabilities present at } \\
\text { all levels of an } \\
\text { enterprise's business } \\
\text { processes (Massiera et } \\
\text { al., 2018). }\end{array}$} & $\begin{array}{l}\text { Customer } \\
\text { relationship } \\
\text { management }\end{array}$ & $\begin{array}{l}\text { Dehdashti Shahrokh et al. } \\
\text { 1396); Nasimi and Amiri } \\
\text { (1396); Ork and Babaei } \\
\text { (1394);Mangali et al. (2016), } \\
\text { Golshahi and Zarei (2016) }\end{array}$ & $\begin{array}{l}\text { Kalka and Morgan } \\
\text { (2019); Masira et al. } \\
\text { (2018); Johnson et al. } \\
\text { (2012); Grant and } \\
\text { Crowns (1999). }\end{array}$ \\
\hline & & $\begin{array}{l}\text { Product } \\
\text { management }\end{array}$ & $\begin{array}{l}\text { Mangali et al. (2015); Moezz } \\
\text { et al. (1397); Hosseinzadeh } \\
\text { Shahri et al. (2015); Rezaei } \\
\text { Dolatabadi and Khaif Elahi } \\
\text { (2006); Goodness and } \\
\text { clarity(1392); Hajipour et al. } \\
(2015) \text {. }\end{array}$ & $\begin{array}{l}\text { Kalka and Morgan } \\
\text { (2019), Masira et al. } \\
\text { (2018); Navarro-Gracia } \\
\text { et al. (2016); Martin et } \\
\text { al. (2015); Murray et al. } \\
\text { (2010); Morgan et al. } \\
\text { (2009); Verhiz and } \\
\text { Morgan (2005); Lee and } \\
\text { Griffin (2004); Leonido } \\
\text { et al. (2004); Leonido et } \\
\text { al. (2002). }\end{array}$ \\
\hline & & Pricing & $\begin{array}{l}\text { Moezz et al. (1397); } \\
\text { Shamabadi and Khodadad } \\
\text { Hosseini (2005); } \\
\text { Hosseinzadeh Shahri et al. } \\
\text { (2015); Respected and } \\
\text { trustworthy (1397); Mangali } \\
\text { et al. (2015); Nasimi and } \\
\text { Amiri (1396); Dehdashti } \\
\text { Shahrokh et al. (1396) }\end{array}$ & $\begin{array}{l}\text { Masira et al. (2018); } \\
\text { Navarro Gracia et al. } \\
\text { (2016); Murray et al. } \\
\text { (2010); Morgan et al. } \\
\text { (2009); Verhiz and } \\
\text { Morgan (2005); Lee and } \\
\text { Griffin (2004); Leonido } \\
\text { et al. (2002). }\end{array}$ \\
\hline & & $\begin{array}{l}\text { Distribution } \\
\text { Promotion }\end{array}$ & \multirow{2}{*}{$\begin{array}{l}\text { Dehdashti Shahrokh and } \\
\text { Pourhosseini (1392 and } \\
\text { 1396); Respected and } \\
\text { trustworthy (1397); Aghajani } \\
\text { and Farzadfar (2013); } \\
\text { Mangali et al. (2015); Moezz } \\
\text { et al. (1397); Hosseinzadeh } \\
\text { Shahri et al. (2015) }\end{array}$} & \multirow{2}{*}{$\begin{array}{l}\text { Masira et al. (2018); } \\
\text { Navarro Gracia et al. } \\
\text { (2016); Martin et al. } \\
\text { (2015); Murray et al. } \\
\text { (2010); Morgan et al. } \\
\text { (2009); Verhiz and } \\
\text { Morgan (2005); Lee and } \\
\text { Griffin (2004); Leonido } \\
\text { et al. (2002); } \\
\text { Cunningham and Hardy } \\
\text { (1974). }\end{array}$} \\
\hline & & & & \\
\hline & & $\begin{array}{l}\text { Sales domain } \\
\text { design }\end{array}$ & $\begin{array}{l}\text { Dehdashti Shahrokh and } \\
\text { Pourhosseini (2013). } \\
\text { Dehdashti Shahrokh et al. } \\
\text { (1396) }\end{array}$ & $\begin{array}{l}\text { Yin Young et al. (2018); } \\
\text { Masira et al. (2018); } \\
\text { Panagopoulos and } \\
\text { Alonitis (2010); Pierce } \\
\text { et al. (2011); Morgan et } \\
\text { al. (2009); Leonido et } \\
\text { al. (2002); Baldoff et al. } \\
\text { (2001); Grant and } \\
\text { Crowns (1999). Masira } \\
\text { et al. (2018). }\end{array}$ \\
\hline
\end{tabular}




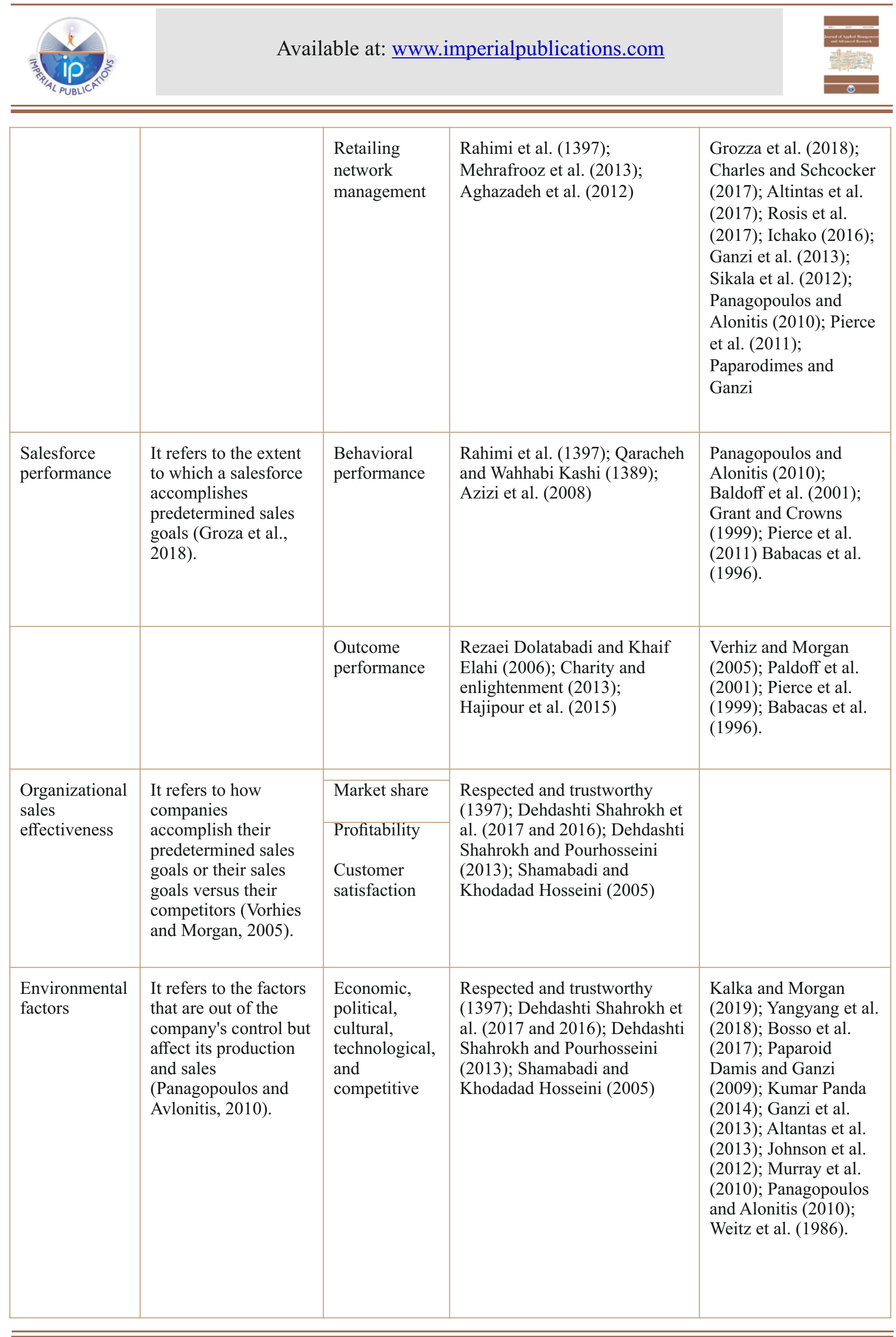




\section{Conclusion}

Companies should take appropriate methods to sell their products - methods that finally result in their sales effectiveness. The data analysis results revealed that a company would achieve sales effectiveness that it can accomplish greater market share, higher profitability, and greater customer satisfaction compared to its own predetermined goals and its competitors, and it makes more investment in its business development. However, none of these is possible without sound strategic orientations. A company should first specify its orientation towards customers and competitors and use all strategic tools, e.g., innovation, costorientation, brand-orientation, and product differentiation, to create a competitive advantage in the market. In this respect, the interviewees asserted that the priorities in a company's strategic orientations should be given to predicting the future needs of customers and considering their tastes, studying and identifying competitors (their weaknesses, strengths, strategies, and goals), recruiting a strong and innovative management team, planning to eliminate unnecessary costs of production and distribution, attempting to be present in regional markets for the sake of brand development, and developing differentiation in products.

Another factor that companies need to make their sales effective and was emphasized by the participants frequently is the development of marketing capabilities and their application to sales. The capabilities of customer relationship management, product management, correct pricing, proper and professional distribution, product promotion, sales domain designing, and retailing network management are some factors enumerated by the participants correctly because weakness in any of them can lead to the failure of all attempts of a company for more sales. In this respect, the human factor - or the so-called salesforce performance - is another major factor for companies' success in sales. This factor has been mentioned in most previous studies. Based on the interviews' results, to ensure effective sales, companies have no way but to recruit a salesforce that is leading both in behavior and outcome. The most frequently mentioned features of behavior performance included rich experience with the ability to establish long-term relationships with retailers, commitment, creativity, knowledgeability, and flexibility. A salesforce's ability to sell a company's new products, gain a greater market share and achieve sales greater than the predetermined goals are among the most frequently noted indicators of the salesforce's outcome performance. In this sense, sales control management, or in other words, the deployment of a mechanism for formal and informal controls in a company for ensuring the effectiveness of salesforce and the control and modification of a company's marketing capability are other primary factors that are necessary for the sales effectiveness of companies. As mentioned in the interviews, training people, including salespeople, continuously evaluating people's performance and providing feedback, motivating people, and creating a cooperation climate are factors that companies have to increase their sales.

It should be noted that environmental or external factors influence all internal activities and efforts of a company for its sales effectiveness. In this respect, economic fluctuations, price volatility of raw material, weak policymaking by the government, changes in regulations and governmental policies, the lack of governmental support, market culture, technological changes of the market, and competitive pressure in the market are some external factors frequently mentioned by the interviewees as the factors that can affect all internal efforts of a company to achieve sales effectiveness and may even deviate all these efforts. So, predicting these factors and planning how to deal with them can greatly ensure companies' success in selling more products.

\section{References}

Adams, P., Freitas, I. M. B., \& Fontana, R. (2019), Strategic orientation, innovation performance and the moderating influence of marketing management. Journal of Business Research, 97,129-140. 
Aghajani, H.A., \& Farzadfar, R. (2013), Export performance model with the competitive capabilities of small and medium citrus exporting companies in the northern provinces of Iran. Iranian Journal of Management Sciences, 8(29), 27-44 • [In Persian]

Aghazadeh, H., Jandaghi, G.R., \& Khalil, M. (2012), Evaluating the effectiveness of life insurance sales methods. Insurance Research Journal, 27(4), 108, 95-71. [In Persian]

Ahmed, M.U., Kristal, M.M., \& Pagell, M. (2014), Impact of operational and marketing capabilities on firm performance: Evidence from economic growth and downturns. International Journal of Production Economics, 154, 59-71.

Albers, S., Mantrala, M. K., \& Sridhar, S. (2010), Personal selling elasticities: A meta-analysis. Journal of Marketing Research, 47(5), 840-853.

Altıntaş, F., kurtulmuşoğlu, F., Altintas, M., Kaufmann, H-R., \& Alkibay, $S$. (2017), The mediating effects of adaptive selling and commitment on the relationship between management control and sales performance. EuroMed Journal of Business, 12, 2, DOI: 10.1108/EMJB-12-2016-0037.

Altuntas, G., Semercioz, F., \& Eregez, H. (2013), Linking strategic and market orientations to organizational performance: the role of innovation in private healthcare organizations. Procedia-Social and Behavioral Sciences, 99, 413-419.

Azizi, S., \& Khorasani, V. (2014), The effect of sales skills on bank counter users' sales performance. Journal of Modern Marketing Research, 4, 4, (15), 56-43, [In Persian].

Babakus, E., Cravens. D. W., Grant, K. Ingram, T. N., \& LaForge, R. W. (1996). Investigating the relationships among sales, management control, sales territory design, salesperson performance, and sales organization effectiveness. Intern. Journal of Research in Marketing 13, 345-363.

Bagheri, S. M., Latifi, S., \& Mohseni Mallardi, S. (2018), Investigating the effect of market orientation on organizational performance in the context of competitive advantage in small and medium industrial companies (Case study: a set of industrial towns in Mazandaran province). Scientific-Research Branch of Business Management Explorations, 10(19), 169-187. [In Persian]

Baldauf, A. \& Cravens, D. W. (1999), Improving the Effectiveness of Field Sales Organizations (A European Perspective). Industrial Marketing Management, 28, 63-72.

Baldauf, A., Cravens, D. W., \& Piercy, N. F. (2001), Examining Business Strategy, Sales Management, and Salesperson Antecedents of Sales Organization Effectiveness, Journal of Personal Selling \& Sales Management, 21:2, 109-122.

Baldauf, A., Cravens, D. W., \& Piercy, N. F. (2005), Sales management control research - Synthesis and an agenda for future research. Journal of Personal Selling and Sales Management, 25(1), 7-26.

Baumgarth, C. (2015), Brand Orientation of Museums: Model and Empirical Results. International Journal of Aarts Management, 11, 3, 30-44.

Behzadnia, P., \& Sanobar, N., (2019). Investigating the Impact of Marketing Capabilities on Export Performance (Case Study: Entrepreneurial Companies Exporting Iranian Agricultural Products). Entrepreneurship Strategies in Agriculture, 6(11), 5867. [In Persian]

Cacciolatti, L., \& Lee, S. H. (2016), Revisiting the relationship between marketing capabilities and firm performance: The moderating role of market orientation, marketing strategy, and organizational power. Journal of Business Research, http://dx.doi.org/10.1016/j.jbusres. 2016.03.067.

Charles H., \& Schwepker Jr. (2017), Psychological, ethical climate, leader-member exchange and commitment to superior customer value: influencing salespeople's unethical intent and sales performance. Journal of Personal Selling \& Sales Management, DOI: 10.1080/08853134.2016.127205.

Cunningham, M.T., \& Hardy, S.M.R. (1974), Evaluating the Effectiveness of Sales and Distribution Systems. International Journal of Physical Distribution, Vol. 4 Iss 3 pp. 133-148.

Dehdashti-Shahrokh, Z., Mazloumi, N., Taghavi-Fard, M.T., \& Biabani, $H$. (2015), The model of the company's strategic orientations and its impact on performance with the moderating role of environmental variables (Case study: Iranian food industry). Strategic Management Research, 22(61), 55-76, [In Persian].

Dehdashti-Shahrokh, Z., Nategh, M., \& Ehsani, R. (2017), Explain the relationship between the organization's marketing capabilities and financial performance. Business Management, 9, 1, 103-128, [In Persian].

Echchakoui, S. (2016), Effect of salesperson personality on sales performance from the customer's perspective: applying socio analytic theory. European Journal of Marketing, https://doi.org/10.1108/EJM-03-20160147.

Evans, K. R., Landry, T. D., \& Li, P.C. (2007), How sales controls affect job-related outcomes: the role of organizational sales-related psychological climate perceptions. J. of the Acad. Mark. Sci, DOI 10.1007/s11747-007-0033-5.

Golshahi, B., \& Zaraei, A. (2015). Identify effective extroverted marketing capabilities in new product production performance: The foundation's customer structure's moderating role. Journal of Modern Marketing Research, 6, 3, (22), 109-126, [In Persian].

Gromark, J., Melin, F. (2010). The underlying dimensions of brand orientation and its impact on financial performance. Journal of Brand Management, 18, 6, 394-410.

Groza, M. D., Locande, D. A., \& Howlett, C. H. (2018), Linking thinking styles to sales performance: The importance of creativity and subjective knowledge. Journal of Business Research, http://dx.doi.org/10.1016/j.jbusres. 2018.03.006.

Guenzi, P., Baldauf, A. \& Panagopoulos, N. G. (2013), The influence of formal and informal sales controls on customer-directed selling behaviors and sales unit effectiveness. Industrial Marketing Management, http://dx.doi.org/10.1016/j.indmarman.2014.04014.

Habibi, S., \& Mira, S. A. (2018), Designing and explaining the strategic orientation model in Iranian knowledge-based companies. Business Management Quarterly, 10 (3), 603-622. [In Persian]

Hajipour, B., Darzian Azizi, A., \& Shamsi Goshki, S. (2012), Explaining the company's product-market strategy and marketing capabilities on market performance. Business Management Research Quarterly, 4 (7). [In Persian]

Hajipour, B., Jafarizadeh, F., \& Rahimi, F. (2016), The Impact of Strategic Orientation and Marketing Capabilities on Export Performance. Business Management Perspective, 22, 87-105. [In Persian]

Hakimi, I. (2017), The effect of organizational culture on marketing capabilities and performance: Explaining the mediating role of extroverted strategic orientations, Business Management (Faculty of Management, University of Tehran), 9, 4, 739-762, [In Persian].

Hosseinzadeh Shahri, M., Habibi, M., \& Heidari, V. (2016), Investigating the Impact of Marketing Capabilities on Sensitivity and Forming a Creative and Timely Marketing Strategy. Modern Marketing Research, 1 (16) 107-128. [In Persian].

Inyang, A. E., Agnihotri, R., \& Munoz, L. (2018), The role of manager leadership style in salesperson implementation of sales strategy: a contingency perspective. Journal of Business \& Industrial Marketing, https://doi.org/10.1108/JBIM-09-2017-0230

Jasuri Shali, F., \& Nasser Fiqhi, F., (2016), Developing a Model for the Impact of Sales and Marketing Strategy on Sales Performance 
Using PLS Approach, Fourth National Conference on Management and Accounting, Tehran, Narkish Information Institute. [In Persian]

Johnson, J. L., Martin, K. D., Saini, A. (2012), The role of a firm's strategic orientation dimensions in determining market orientation. Industrial Marketing Management, 41, 715-724.

Kaleka, A., Morgan, N. A. (2019), How marketing capabilities and current performance drive strategic intentions in international markets. Industrial Marketing Management, 78,108-121.

Kheiri, B., \& Roshani, A. (2013), Investigating the Mediating Role of Marketing Capabilities in the Relationship between Strategic Orientations and Organizational Performance: A Case Study in Bank Melli Iran. Management, 10 (29), 97-113, [In Persian].

Kue Na, Y., Kang, S., \& Yeon Jeong, H. (2019), The Effect of Market Orientation on Performance of Sharing Economy Business: Focusing on Marketing Innovation and Sustainable Competitive Advantage. Sustainability, 11, 729, 1-19.

Lee, Y.K., Kim, S.H., Seo, M.K., \& Kyle Hight, S. (2015), Market orientation and business performance: Evidence from franchising industry. International Journal of Hospitality Management, 44, $28-37$

Leonidou, L. C., Katsikeas, C. S., \& Samiee, S. (2002), Marketing strategy determinants of export performance: a meta-analysis. Journal of Business Research, 55, 51-67.

Mangali, N., Rezaei, R., \& Safa, L. (2015), Investigating the Impact of Marketing Capabilities on the Performance of Small and Medium Businesses. Journal of Entrepreneurship in Agriculture, 3, 4, 116[In Persian].

Martin, S. L., \& Javalgi, R. G. (2015), Entrepreneurial orientation, marketing capabilities and performance: The Moderating role of Competitive Intensity on Latin American International New Ventures. Journal of Business Research, http://dx.doi.org/10.1016/j.jbusres.2015.10.149.

Massiera, P., Trinchera, L., \& Russolillo, G. (2018), Evaluating the presence of marketing capabilities: A multidimensional, hierarchical index. Recherche et Applications en Marketing, 33(1), $30-52$.

Mehrafrooz, M., Mortazavi, S., \& Kafashpour, A. (2013), The role of moderating sales skills in sales orientation and customer orientation on the sales force performance of insurance companies. Journal of Modern Marketing Research, 2, (9), 85-106, [In Persian].

Moazez, H., Fathi, M.R., \& Rabiee, A. (2018), Designing a strategic production model with a structural equation model approach (Case study: Saipa Automotive Company). Management Research in Iran, 22, 2, 79-102, [In Persian].

Mohtaram, R., \& Movasegh, M., (2018), Investigating the effect of export market orientation and marketing mix adaptation on export performance (Case study: Companies exporting non-oil products). Business Management (Faculty of Management, University of Tehran), 10(1), 165-186, [In Persian].

Morgan, N. A., Vorhies, D. W., \& Mason, C. H. (2007), Market Orientation, Marketing Capabilities, and Firm Performance. Strategic Management Journal, 30, 909-920.

Mortazavi, M., Rasouli-Ghahroudy, M., \& Rostami, A. (2015), Investigating the Impact of Organizational Innovation and Overall Cost Leadership Strategy on Organizational Performance through Competitive Advantage. Journal of Development and Transformation Management, 27, 17-25, [In Persian].

Murray, J. Y., Gao, G. Y., \&Kotabe, M. (2011), Market orientation and performance of export ventures: the process through marketing capabilities and competitive advantages. J. of the Acad. Mark. Sci., 39, 252-269.

Naieji, M. J., Alam-Najafi, S.M., Nourani, S. S. (2018), The Impact of Strategic Trend on Small and Medium Business Growth Mediated by Brand and Market Performance. Strategic Management Studies, 33, 45-74, [In Persian].

Navarro-García, A., Peris-Oritz, M., \& Barrera-Barrera, P. (2016), Market intelligence affects perceived psychic distance, strategic behaviors, and export performance in industrial SMEs. Journal of Business \& Industrial Marketing, Vol.31, Iss 3.

Ork, F., \& Babaei Zakliki, M.A. (2015), Evaluating the relationship between marketing capabilities and organizational performance in food companies in Tehran. Brand Management Quarterly, 2(4), 147-175[In Persian]

Panagopoulos, N. G. \& Avlonitis, G. J. (2010). Performance implications of sales strategy: The moderating effects of leadership and environment. Intern. J. of Research in Marketing 27, 46-57.

Panagopoulos, N. G., \& Avlonitis, G. J. (2010). Performance implications of sales strategy: The moderating effects of leadership and environment. Intern. J. of Research in Marketing, 27, 46-57.

Panagopoulos, N. G., Johnson, C. M., \& Mothersbaugh, D. L. (2015), Does the choice of sales control conceptualization matter? An empirical comparison of existing conceptualizations and directions for future research, Journal of Personal Selling \& Sales Management, DOI: 10.1080/08853134.2015.1016952

Paparoidamis, N. G. \& Guenzi, P. (2009), An empirical investigation into the impact of relationship selling and LMX on salespeople's behaviors and sales effectiveness. European Journal of Marketing, 43, 7/8 pp. 1053-1075.

Piercy, N. F., Cravens, D. W. \& Morgan, N. A. (1999), Relationships between Sales Management Control, Territory Design, Salesforce Performance, and Sales Organization Effectiveness. British Journal of Management, Vol. 10, 95-111.

Piercy, N. F., Low, G. \& Cravens, D. W. (2011), Country differences concerning sales organization and salesperson antecedents of sales unit effectiveness. Journal of World Business, 46, 104-115.

Rahimi, F., Darzian-Azizi, A., \& Ghanavatpour, A. (2018), Behavioralfunctional consequences pattern of salesforce listening skills. New Marketing Research, 8, 4, 27-44, [In Persian].

Rahimnia, F., \& Sajjad, A. (2016), The effect of strategic orientations on companies' performance is located in Khorasan Science and Technology Park due to organizational innovation. Journal of Innovation Management, 5, 2, 87-114, [In Persian].

Rastegar, A.A., \& Hemmati, A. (2015), Measuring the impact of competitive strategies on organizational performance. Fourth International Conference on Strategic Management, University of Tehran, [In Persian].

Rastegari, M., \& Tayfouri, A. (2016), Perspectives on the situation of food waste in Iran. The First International Congress on Healthy Agriculture. Nutrition, and Society (Tehran, July 2015), [In Persian].

Rezaei Dolatabadi, H., \& Khaefollahi, A.A. (2006), A model for determining the impact of market orientation on business performance concerning marketing capabilities in the chemical industry. Human Sciences MODARES, 10, 1, 131-161, [In Persian].

Shamabadi, M.A., \& Khodadad Hosseini, S.H. (2005), Designing an export marketing model for Iranian hand-woven carpets. Human Sciences MODARES, 79-100, [In Persian].

Theodosiou, M., Kehagias, J., \& Katsikea, E. (2012), Strategic orientations, marketing capabilities and firm performance: An empirical investigation in the context of frontline managers in service organizations. Industrial Marketing Management, 41, $1058-1070$.

Tutar, H., Nart, S., \& Bingöl, D. (2015), The Effects of Strategic Orientations on Innovation Capabilities and Market Performance: The Case of ASEM. Procedia-Social and Behavioral Sciences, 207, $709-719$.

Vazifeh Doost, H., Hajloo, M.H, \& Nazarpour, F. (2013), Investigating 
Using PLS Approach, Fourth National Conference on Management and the effect of implementing Porter's competitive strategies on meeting the market-oriented needs of the petrochemical company's customers. Organizational Culture Management, 11, 3, 121-139, [In Persian].

Vorhies, D. W., \& Morgan, N. A. (2005), Benchmarking Marketing Capabilities for Sustainable Competitive Advantage. Journal of Marketing, Vol. 69, 80-94.

Wong, H. Y., \& Merrilees, B. (2005), A brand orientation typology for SMEs: a case research approach. Journal of Product \& Brand Management, 14/3, 155-162. 